\title{
TEENAGER RELATIONSHIP IN NICOLA YOON'S NOVEL EVERYTHING, EVERYTHING
}

\author{
Nurtia Pratiwi Siahaan, Sri Wulan \\ Faculty of Literature, Universitas Islam Sumatera Utara, \\ Medan, Indonesia \\ e-mail: nurtiasiahaan7@gmail.com
}

Received: 2020-08-04

Accepted: 2020-11-23

\begin{abstract}
This study was conducted to give an overview to all people about the portrayal of teenager relationship and its negative impact in the novel. This study applies qualitative method which collects the data taken from the novel that have been read. The result shows that the relationship in the novel is portrayed as an unhealthy relationship. It is described as if it were an adult relationship. Their relationship is too romantic and too intimate. Such relationship is, of course, not suitable for their age as the protagonist and her lover are still teenagers. Consequently, the relationship result in negative impacts. The negative impacts which can be found in the novel are opposition, carelessness, and lying. These impacts happen to the protagonist after she has the love relationship. On the basis of the result of this study, it can be concluded that having an unhealthy relationship during adolescence may cause a negative impact on themselves and family.
\end{abstract}

Keywords: teenager, relationship, intimate, lying.

\section{Introduction}

Everything, Everything is 310 page novel, written by Nicola Yoon. Nicola Yoon is the Jamaica - American author, born in Jamaica October 1, 1972. She is well known for writing the 2015 young adult novel Everything, Everything, the New York Times best seller and being the basis for a 2017 film of the same name in 2016. Yoon was inspired to write her debut novel, Everything, Everything, after the birth of her daughter. She wants to write a book that reflects her child on the pages. Her first time mother worries about protecting her baby from danger gave her the idea to write a story about a 17 year old girl who needed the same level of protection. Yoon took three years to write a book, write early in the morning while working full time and raise her baby daughter. Her husband, Korean-American graphic designer David Yoon, drew an illustration.

Everything, Everything was released in September 2015 and debuted as No. 1 New York Times best seller for young adult hardcover book, the book spend 40 weeks on the best seller list. Everything, Everything has received many awards such as south Carolina book awards for young adult (2018), Evergreen Teen Book Award (2018), Rhode Teen Book Award (2017).

This novel talks about the unhealthy relationship between Madeline with her firstknown man who has just moved next to her house. In various ways, Olly wanted to meet Madeline who was confined in her room. They fell in love after greeting each other 
through the window of each room. They communicate through intermediaries such as email and messages.

This study is concerned with the portrayal of teenager relationship of this novel. The reason why this topic is chosen because in this millennial era, there are many cases that we often encounter in adolescent love relationships or children who are new to love, such as free sex and pregnancy before marriage.

Therefore, it is regarded that this study is very useful to portray the teenager's relationship and how the relationship results in negative impact. It is hoped that through this study, moral lesson can be conveyed. This research has two purposes. They are to reveal how teenager relationship is portrayed in the novel, and to find out the negative impacts of the relationship to the protagonist.

The study focuses on two points of discussion. Two points of discussion are analyzed based on the result of research by Zhiyan et. al (2019). There are two impacts of teenager relationship based on Zhiyan et. al.'s research. They are emotional \& behavioral consequences. But this study focuses only on behavior problems which can be found in the novel.

\section{Literature Review}

Romantic relationship have been considered as a hallmark of adolescence in the west (Collins, et. Al, 2009). Young people spend a great deal of time thinking about, talking about, and being in romantic relationships (Furman, 2002:177-180). But recently, they have become popular in Indonesia societies as well. Globalization, westernization and the internet boom has made these relationships more common. Most teenagers will experience feelings of butterflies in the stomach, interest and the formation of a unique bond between two people of the opposite sex. They experience a relationship like that when two people fall in love, the situation is where romantic relationships are. Basically, romantic relationships are recognized together as ongoing voluntary interactions that are usually characterized by expressions of affection and possibly current or anticipated sexual behavior (Brown et al. 1999, Furman \& Collins 2008, Manning et al. 2006).

Romantic relationships have an important impact on the lives of teenagers. A healthy successful relationship can make teenagers more self-aware, confident, positive and interactive. On the other hand, unsuccessful relationships can actually hamper adolescent's moral, social and intellectual development. Although most adolescents experience the negative effects of a relationship breaking up, sooner or later find ways to divert their minds and then enter into new relationships. But if teens experience a series of relationships, failing each of them can make teens lose self-confidence, form negative self-identities and be an important cause behind depression and suicide among adolescents.

Basic to Sullivan's theory (1953), there are five basic social needs that motivate people to bring about certain types of interpersonal situation, they are: tenderness, companionship, acceptance, intimacy, and sexuality.

Table 2.1Summary of Sullivan's Stages of Development

\begin{tabular}{|c|c|c|c|c|}
\hline Stage & Age & $\begin{array}{c}\text { Significant } \\
\text { others }\end{array}$ & $\begin{array}{c}\text { Interpersonal } \\
\text { proses }\end{array}$ & $\begin{array}{c}\text { Important } \\
\text { learnings }\end{array}$ \\
\hline Infancy & 0 to 2 & $\begin{array}{c}\text { Mothering } \\
\text { one }\end{array}$ & Tenderness & $\begin{array}{c}\text { Good mother/ } \\
\text { bad mother, good } \\
\text { me/ bad me }\end{array}$ \\
\hline
\end{tabular}




\begin{tabular}{|c|c|c|c|c|}
\hline Childhood & 2 to 6 & Parents & $\begin{array}{c}\text { Protect security } \\
\text { through imaginary } \\
\text { playmates }\end{array}$ & $\begin{array}{c}\text { Syntax is } \\
\text { language }\end{array}$ \\
\hline Juvenile era & 6 to $81 / 2$ & $\begin{array}{c}\text { Playmates of } \\
\text { equal status }\end{array}$ & $\begin{array}{c}\text { Orientation toward } \\
\text { living in the world } \\
\text { of peers }\end{array}$ & $\begin{array}{c}\text { Competition, } \\
\text { compromise, } \\
\text { cooperation }\end{array}$ \\
\hline Preadolescence & $81 / 2$ to 13 & Single chum & Intimacy & $\begin{array}{c}\text { Affection and } \\
\text { respect from } \\
\text { peers }\end{array}$ \\
\hline $\begin{array}{c}\text { Early } \\
\text { adolescence }\end{array}$ & 13 to 15 & $\begin{array}{c}\text { Several } \\
\text { chums }\end{array}$ & $\begin{array}{c}\text { Intimacy and lust } \\
\text { toward different } \\
\text { persons }\end{array}$ & $\begin{array}{c}\text { Balance of lust, } \\
\text { intimacy and } \\
\text { security } \\
\text { operations }\end{array}$ \\
\hline $\begin{array}{c}\text { Late } \\
\text { adolescence }\end{array}$ & 15 --- & Lover & $\begin{array}{c}\text { Fusion of intimacy } \\
\text { and lust }\end{array}$ & $\begin{array}{c}\text { Discovery of self } \\
\text { and the world } \\
\text { outside of self }\end{array}$ \\
\hline
\end{tabular}

From the table above it can be seen that the interpersonal process that exists in adolescent relationships are intimacy and lust.

Intimacy grows out of the earlier need for tenderness but is more specific and involves a close interpersonal relationship between two people who are more or less of equal status. Intimacy is an integrating dynamism that tends to draw out loving reactions from the other person, thereby decreasing anxiety and loneliness, two extremely painful experiences. Because intimacy helps us avoid anxiety and loneliness, it is a rewarding experience that most healthy people desire (Sullivan, 1953).

On the other hand, lust is an isolating tendency, requiring no other person for its satisfaction. It manifests itself as autoerotic behavior even when another person is the object of one's lust. Attempts at lustful activity are often rebuffed by others, which increases anxiety and decreases feelings of self-worth. In addition, lust often hinders an intimate relationship, especially during early adolescence when it is easily confused with sexual attraction.

A relationship must have an impact, both positive and negative. Romantic experiences are believed to play important roles in the development of an identity, the transformation of family relationships, the development of close relationships with peers, the development of sexuality, and scholastic achievement and career planning (Furman and Shaffer, 2003). Research on the effects of adolescent romantic relationships has increased significantly in the past decade, yet almost all of the studies have been conducted in Western societies. Culturally diverse research is needed to further the understanding of the development and impact of romantic relationships in adolescence.

It is said that Adolescents romantic relationships have been associated with higher levels of depression, although their links with externalizing behavioral problems remain unclear (Zhiyan, et. al 2009). In their research, the results showed that romantic involvement in adolescence, especially in early adolescence, was associated with more behavior problems. Breakups in romantic relationships were an important factor in producing the negative emotional and behavioral consequences. Romantically involved girls experienced higher levels of depressive symptoms, while romantically involved boys had higher levels of externalizing behaviors, compared to their non-dating peers. 
The results also indicated that the adverse impact was stronger for those involved in romantic relationships at younger ages.

\section{Research Method}

This study applies qualitative research. Dowson (2002) in Hariani and Wulan (2019) explains that qualitative research explores attitudes, behavior, and experiences through such method as interviews. He also says that in qualitative research, the writer is able to find out, define, describe, and explain the substance of narration. Therefore, this study presents the analysis and findings in the qualitatively descriptive form. This study explores two aspects in the novel as the central phenomena: the portrayal of the teenager relationship and its negative impacts.

\section{Discussion}

\subsection{The Portrayal of Teenager Relationship \\ 4.1.1 Too Romantic}

For the first time, the protagonist listens to romantic words she gets from a man who falls in love with her. In the novel, there are several quotations that show a romantic side. As in the following:

"It looks like someone sprinkled chocolate across your nose and cheeks." His eyes travel down to my lips and back up to my eyes. "Your lips are pink and they get pinker when you chew on them."(Yoon, 2015: 127).

It shows the view of the protagonist at the time. For the first time she listens to romantic words or sentences. She has never heard before, and the reason she lets Olly talk like that because she is unable to stop the romantic words from him.

At the same time, Maddy not only gets a romantic word, but also a romantic treatment from Olly when they have vacation in Hawaii.

"He runs his hands along the length of my arms, slowly pulling me toward him at the same time. He touches his forehead to mine when we're finally close enough. His eyes are blue fire. He looks like a starving man, like he could devour me all at once."(Yoon, 2015:222).

Madeline has never been in contact with a man in her life. Olly's attitude towards her is considered romantic. In this condition, Olly's treatment of Madeline makes Madeline forget about her illness that touching someone else will lead to a big mistake. This is not the first time he has been in touch with Olly, but Madeline still considers the romantic attitude carried out by Olly as a form of her love for Madeline.

In another situation, Madeline thinks that Olly's attitude and all of Olly's words are real to Madeline who falls in love for the first time. While Olly who sees Madeline thinks like a scared person because she has been doubtful about her feelings. Olly tries to approach Maddy and looks at her and convinces Maddy does not have any doubt what she has thought before.

"He's silent. The more I think about what he's saying, the more upset I get. But then I realize that he's not trying to dismiss or belittle my feelings. He's just scared. Given my lack of choices, what if I've just chosen him by default? He takes a breath. "In my head I know I've been in love before, but it doesn't feel like it. Being in love with you is 
better than the first time. It feels like the first time and the last time and the only time all at once."(Yoon, 2015: 238).

She has such thought because she knows that, for Olly maybe, this is not the first time. But Olly has the same feelings as Maddy for the first time. Maddy has made Olly fall in love with her in a different way. And Olly says it very loud because he wants Maddy to know it as soon as possible.

Olly's attitude that makes Maddy fall in love quickly is because Olly treats Maddy like a princess from a fairyland that he meets in the real world. Even Maddy's beauty and kindness cannot be explained only in words when they see face to face directly. Even if romantic words and good treatment are not enough for Olly to describe who Maddy really is. Having the same feelings does not make Olly thinks that Maddy is an ordinary woman like his relationship with other women before. Being romantic does not mean always giving flowers, or giving glamorous gifts. The romantic attitude that Olly preserves is very simple and creates Maddy feel happy when she is together with him. Maddy does not even think that Olly has a romantic side.

\subsubsection{Too Intimate}

An intimate is an interpersonal relationship that involves physical or emotional intimacy between two people. Physical intimacy is characterized by romantic and passionate attachment or sexual activity. Besides they have romantic relationship, they also engage in intimate relations while they are on vacation in Hawaii. The quotation below shows the intimacy in their relationship.

"I squat, shift, and push up. I'm unstable almost immediately and begin to fall backward. Olly's suddenly right next to me, his hands on the bare skin of my ankles, holding me steady. Every nerve in my body migrates to where he touches. The skin under his hand sparks to life, every cell alight with feeling. I feel as if I've never been touched before."(Yoon, 2015: 126)

It can be proved that the incident can be the beginning of a relationship that they forget into further and more intimate. And even though they still feel awkward with each other after the incident, they will be more courageous to do other things in the future.

Maddy also realizes that he has gone too far to risk going on vacation together with Olly and tried to fight his fear by doing things that were considered to be too far away in adolescent relationship. But Maddy still wants to continue what both of them have done before.

"He tugs my hand just slightly. It's a question, I know, and I look up from the miracle of our hands to the miracle of his face and eyes and lips moving closer to mine. Did I move? Did he? His breath is warm and then his lips are brushing butterfly-soft against mine. My eyes close on their own."(Yoon, 2015: 137)

Like in drama, they kiss like a scene in a romantic comedy they are playing. Maddy's fear of contacting with others just disappears. This proves that Maddy is fine when doing body touch. 
On the other hand, the dating style that they do is actually already unhealthy and more to the adult style. They do kissing scenes, sleep together in one bed and hug each other, making them forget their age is still a teenager.

"He climbs back into bed and throws an arm out. I curl into him, put my head into the Maddy shaped nook of space between his neck and shoulder. "I love you, Maddy." II love you, Olly. I loved you before I knew you."We drift off to sleep curled around each other, neither of us talking, just letting the world make some noise for us for a while because all the other words don't matter right now." (Yoon, 2015: 238)

Maddy is getting used to things related to intimacy in dating. Although she knows it is wrong, then does not make Maddy to refuse offers from her lover not to sleep together. And this is not new for Maddy to sleep together in one bed while hugging when going to sleep.

At different times, Maddy and Olly will go to the beach where it is the first and last place that they will visit. Maddy is very glad to visit the beach with Olly. Maddy will be wearing a dress that has one size only. While Olly, who looks dashing in a tight black t-shirt, black shorts, and black sandals such as the death toll, which is able to make Maddy feel passionate. The quotation below illustrates how excited Olly is in Maddy's eyes so Maddy wants to kiss Olly at that moment.

"His eyes are a clear, summer-blue lake that I can't see the bottom of. I touch my lips to his. He hops down from the railing, pushing me back against a table. Before I know it, I'm flush against him and he's kissing me with a groan. I open for him and we kiss until I can't breathe, until my next breath is one of his. My hands are on his shoulders, on the back of his neck, in his hair. My hands don't know where to stop. I am electrified. I want everything and all at once.”(Yoon, 2015: 240)

Based on the quotation above, for Maddy, no one has eyes as beautiful as Olly and he has distinctive aroma. For the umpteenth time, they have sexual intercourse through their lips, and makes Maddy hard to breathe. In this quotation, it is shown that having sex in a love relationship is not only with free sex but it can also be through the touch of a person's body against others which causes excessive lust.

\subsection{The Negative Impact of the Relationship to the Protagonist in the Novel}

Having a relationship in the context of love certainly sounds ordinary because in general all teenagers do it. But it is different from unhealthy dating style. Teenagers who have unhealthy relationship during dating can result in negative impacts. In the novel, the protagonist has a boyfriend whom she has just met and he lives next to her house. When first time they are dating, their style is mediocre, nothing strange. But as time goes by, the protagonist wants to meet her boyfriend secretly. Without her mother's permission. Consequently, the relationship causes negative impact to the protagonist.

Below are the three negative impacts that arise because of the protagonist's unhealthy relationship.

\subsubsection{Opposition}

In this novel, there is some resistance made by the protagonist against his life. From putting up a fight against her parents, herself, and until about the love she faces 
during his life. The resistance done by the protagonist can actually endanger herself. Basically, the resistance itself is in everyone, especially teenagers. In adolescence, a lot of resistance because they think they are right so the resistance she gives to others also causes a problem.

"It feels strange not to talk to my mom about something, someone, who's becoming so important to me. My mom and I are drifting apart, but not because we're spending less time together. And not because Olly's replacing her. We're drifting apart because for the first time in my life, I have a secret to keep." (Yoon, 2015: 101)

Based on the protagonist's words above, the protagonist is not accustomed to oppose her mother. The habit of always sharing stories with her mother about everything has become the thing she always does when they both have something to tell. But this time, the protagonist is contrary to her desire to tell about Olly in front of her mother. The protagonist is afraid of lying to her mother and her feelings but this time she has to hold it back until the right time comes. She will tell her mother who Olly is and why he can be someone so important to the protagonist.

The fear that the protagonist has been facing is because she has broken her mother's rules. Constantly exchanging messages by email with Olly until late at night makes the protagonist violate the sleep schedule that has been set by her mother.

On the other hand, Olly has a problem in his family. And the protagonist who sees him directly from the window feels very worried and immediately escaped from her mother's arms.

"I fly out of the room and down the hall. I'm through the air lock and out the door in no time at all. I don't know where I'm going, but I have to get to him. I don't know what I'm doing, but I have to protect him. I sprint across our grass to the edge of the lawn closest to Olly's house"'(Yoon, 2015: 135-136)

From the quotations above, it is hard for the protagonist to think clearly. seeing Olly being attacked by his father makes the protagonist unable to just stay quiet. the protagonist wants to help Olly against Olly's father and she cannot fight her desire not to come out of her house. Of course, it makes the protagonist confused with what she will do. within a few minutes, the protagonist immediately rushes out of the house to meet and check Olly conditions. Basically, she is not allowed to go out by her mother because she has been given the previous rules. But, because of love she breaks one of the rules given by her mother.

Protagonist's mother will not allow her daughter to be contaminated with the outside world, so rules are made for her daughter to be safe from the outside world. But after the protagonist knows Olly and has a relationship with him, the protagonist becomes a dissident and she often violates the rules that her mother makes for her goodness. And the rules that has been broken is leaving the house without her mother's permission to meet Olly who is fighting with his family.

\subsubsection{Carelessness}

Carelessness is one of those behaviors by which one can no longer think clearly about what she is doing, and then makes her feel guilty at the end. Usually, carelessness 
is done by teenager who is falling in love, and then it makes them look like they do not have certain directions in making decisions because they think that their age is still young.

"I know she's not upset that I bought new clothes. She's upset that I didn't ask her opinion and bought them in colors that she didn't expect. She's upset with the change she didn't see coming. I resent and understand it at the same time. She's had to control so many things to keep me safe in my bubble.'(Yoon, 2015: 114)

Based on that quotation, the protagonist seems little careless with her attitude which is a big question mark of people around her. The protagonist's attitude obviously seems very strange lately because she buys a lot of new clothes, new shoes, and more recently she has not been focused on her mother and the surroundings. She just keeps thinking about Olly. Because of her carelessness, people around her disappointment and anger at his new attitude is a little strange.

In another time, the protagonist takes a very careless action for herself. She chooses to leave the house without permission from her mother.

"I'm sorry. I wasn't thinking. I just wanted to make sure he was OK.I rub my hands down my forearms. My heart beats so fast it hurts. The enormity of what I've done overwhelms me and I'm trembling."(Yoon, 2015: 137)

It can be seen that the protagonist feels sick after going out to meet Olly. This makes her mother angry at her because she is too fast to take decision to meet Olly. She does not think there is a danger. The protagonist almost risks her life for the person she has just met.Thus, the protagonist's carelessness makes her mother really angry and also worried.

As a result of the protagonist's careless actions, Carla also receives anger from the protagonist's mother because Carla lets Maddy to meet Olly whom Maddy has just known.

"She went outside. Because of him. Because of you. She turns to face me. She put her life at risk and she's been lying to me for weeks. She turns back to Carla. "You're fired. "No, please, Mom. It wasn't her fault. "She cuts me off with a hand. "Not only her fault, you mean. It was your fault, too."(Yoon, 2015: 140)

Carla's biggest mistake is to let the protagonist meet Olly and make them fall in love each other until they are willing to do careless things that can endanger themselves.

As a caregiver, Carla has given a gap for them to meet each other. Even though she is really careful to take care Maddy, it cannot ensure the protagonist's mother to think that Carla is careless. Maddy's mother thinks that Carla does not monitor and take care her daughter well when she is not at home.

\subsubsection{Lying}

Lying is one of the ways used by many people to hide things from others, and lying is also often done by people who are afraid of his/her actions. Lying is a form or type of untrue statement conveyed to others. The element of fear also pushes someone to lie to the person they love and the person who is around her/her.

"Cat video," I say through a mouthful of turkey. Ugh, wrong thing to say. Carla lives for cat videos. She thinks they're the only thing the 
Internet is good for. She comes around, stands behind me, and reaches for the laptop. I drop my sandwich and hug the laptop close to my chest. I'm not a good liar, and I say the first thing that pops into my head. "You don't want to see this one, Carla. It's bad. The cat dies."

(Yoon, 2015: 61)

In the quotation above, it can be seen that fear of something makes the protagonist lie to Carla. Although the protagonist tries not to lie, she still has to lie to cover up what she is doing. The protagonist secretly sends a message to the person who just moves next to her house via email which makes Carla more curious about what is doing while smiling staring at her laptop. 'The protagonist conducts it because she thinks if she lies, then Carla will not bother her anymore.

Day by day, she convinces that what she is doing is fine. It is time for her to dare to talk to Carla about her plan.

"You know I don't like saying no to you. You're a good girl. "I rush right through this opening. "He'd get decontaminated and sit across the room, far, far away from me and only for fifteen minutes. Thirty minutes at the most. "She shakes her head, but it's not a firm shake. "It's too risky. And your mother would never allow it." "We won't tell her," I say instantly. She gives me a sharp, disappointed look. "Do you girls really find it so easy to lie to your mamas?" (Yoon, 2015: 66)

It shows that she wants Carla to hide the plan from her mother. Her plan is to meet Olly without her mother's permission. That is proof that she opposes her mother's rule through lying.

In another chance, she does something which her mother and Carla does not know. Here a quotation about that:

"She doesn't know about the touch on my ankle, the holding hands, the almost haredbreath. I should tell her, but I don't. I'm afraid she'll stop our visits. Another lies to add to my growing count. Olly's now the only person in my life that I haven't lied to."(Yoon, 2015: 131)

From the confession above, the protagonist does not want to discuss their relationship with Carla. She is afraid that if she tells a problem that she has, Carla will get angry and she will not give permission again to Olly to meet Maddy. Maddy keeps lying about how difficult their relationship is. But Maddy chooses to lie so Carla will let Olly to meet her another time. Going through an unhealthy relationship requires Maddy to keep hiding their activities from everyone.

\section{Conclusion}

Based on the analysis of the problem in the novel, the conclusion is found. The protagonist's relationship as a teenager makes everyone around her worried completely. The protagonist's relationship is clearly as the form of a resistance by lying in order to maintain her relationship with her family and boyfriend so that she looks fine.

The teenager relationship is portrayed in this novel by two means of description. First, the relationship is described too romantically. Both the protagonist and her lover show themselves as romantic lovers. Then, their relationship is portrayed as intimate love. Romantic and intimate love relationship is considered not suitable for teenagers since 
such states of relationship should be possessed by adult's relationship. Therefore, their relationship is considered unhealthy relationship.

Besides, the unhealthy relationship causes negative impacts to the protagonist. From the analysis, it can be concluded that there are three negative impacts which happen to the protagonist in the novel. The first impact is opposition. The protagonist opposes her mother's rule since she has a relationship. The second is carelessness. And the last is lying. The protagonist becomes a liar, especially to her mother. All these negative Impacts appear since the protagonist has such love relationship.

\section{References}

Brown, B.B., Feiring, C., \& Furman, W. (1999).The development of romantic relationships in adolescence. New York: Cambridge University Press.

Collins,W.A. Welsh, D. \& Furman, W. (2009). Adolescent romantic relationships. Annual Review of Psychology, 60: 631652.https://doi.org/10.1146/annurev.psych.60.110707.163459

Dweck, C. S. (1999). Self-theories: Their role in motivation, personality, and development. Philadelphia: Psychology Press.

Furman, W. (2002). The Emerging Field of Adolescent Romantic Relationships. Current Directions in Psychological Science, 11(5), 177180. https://doi.org/10.1111/1467-8721.00195

Furman, W., \& Shaffer, L. (2003). The role of romantic relationships in adolescent development.In P. Florsheim (Eds.) Adolescent romantic relations and sexual behavior: Theory, research, and practical implications. Mahweh: Lawrence Erlbaum.

Hariani, R. F., \& Wulan, S. (2019). Depression in Jojo Moyes' Me Before You. KnE Social Sciences, 3(19), 770-783. https://doi.org/10.18502/kss.v3i19.4903

Huston, T., L., et al (2001).The Connubial Crucible: Newlywed Years as Predictors of Marital Delight, Distress, and Divorce. Journal of Personality and Social Psychology,80, 237-52.doi: 10.1037/0022-3514.80.2.237

Steinberg, L. (2014). Age of opportunity: Lessons from the new science of adolescence. Boston, MA: Houghton Mifflin Harcourt.

Sullivan, H. S. (1953). The interpersonal theory of psychiatry. New York: Norton \& Co. Zhiyan, C. et. al. (2009). Emotional and Behavioral Effects of Romantic Relationships in Chinese Adolescents. Journal of youth and adolescence. 38: 1282-93. Doi. 10.1007/s10964-009-9405-0 